\title{
Scientific basis and rules of thumb in civil engineering: conflict or harmony?
}

\author{
L. CZARNECKI ${ }^{1 *}$ and D. VAN GEMERT ${ }^{2}$ \\ ${ }^{1}$ Building Research Institute (ITB), 1 Filtrowa St., 00-611 Warsaw \\ ${ }^{2}$ Katholieke Universiteit Leuven, Oude Markt 13, 3000 Leuven, Belgium
}

\begin{abstract}
Science and engineering intermingle in the area of construction. Engineering works, often of great dimensions and design life cycle of many decades, have to be designed on a scientific basis since the safety of hundreds of users depends on their design. The task of scientific institutions is to define the construction performance within categories that correspond to the contemporary level of knowledge and technology. A construction appraiser who speaks out in a way that ensures unquestionable competence about the performance of elements and buildings (existing and under construction), should be convinced of the scientific basis of his opinions. A comparison of construction sections vs. basic requirements presents an archetype of the science of construction. A matrix of the science of construction reveals its multi-faceted nature; if related to time - the issue of durability has to be considered, and if related to the scale - the complexity. Defining the construction performance in terms of technical features is a constant search for a relationship between the material model and the usability model of a building. The construction industry uses a lot of "rules of thumb", more than any other sector of technology. In the era of computer-aided design, CAD, and building information modelling (BIM), those rules of thumb remain invaluable verification tools.
\end{abstract}

Key words: building performance, appraiser, matrix of the science of construction, rules of thumb, durability, complexity, diversified development.

\section{Introduction}

It is better to be roughly right than precisely wrong. J.M. Keyness, 1924

The design of a construction or the evaluation of the performance of buildings and construction elements in a way that ensures unquestionable competence should be scientifically based. This is even more important as such evaluations often concern large-scale engineering works, which determine the safety of many users and a design life cycle of many decades. This is even more important today, when well sustainable development requirements and necessities are imposed by building laws. Aiming at ensuring the durability and reliability of buildings means that almost all of them have to be controlled in the course of design, construction and use. The issues of infrastructure security and sustainable development should be considered more broadly as well. Given that at present many buildings are entering a period of a high degradation rate due to their age, that disasters such as floods and fires occur more often, and also that some buildings and structures such as nuclear installations, dams and dikes, present a significant permanent risk for the environment, thus requiring monitoring from the very beginning of their operation, the appraisal issues cover an ever broader field of expertise. This requires a constant intake of new knowledge.

The issues included in the title of this study were partially presented in the monthly Materiaty Budowlane [1] in an article titled "Shaping the scientific basis for the development of the

*e-mail: 1.czarnecki@itb.pl construction industry" published in connection with the 70th anniversary of the Building Research Institute.

\section{Defining building performance}

The primary task of universities and research institutes in the scientific discipline of construction is to continuously define building performance in a manner consistent with the current level of knowledge and technology. This means permanently seeking true solutions [2] - the relationship between the two corresponding models [3]: the material model (material model is used here to represent materials, analyses and geometries) and the usability model, which combines properties and requirements (Fig. 1).

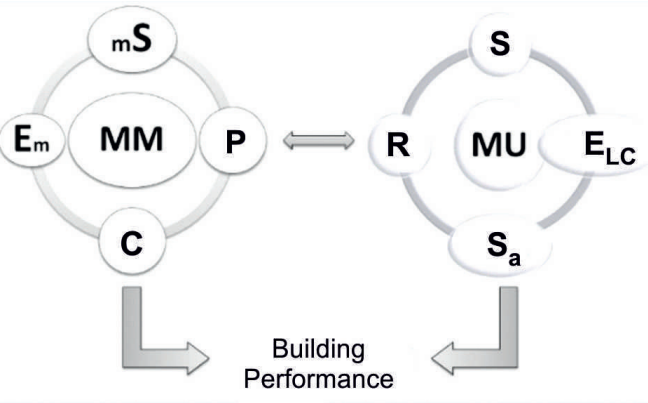

Fig. 1. Relation between material model (MM) and usability model (UM): $\mathrm{P}$ - properties, $\mathrm{mS}$ - microstructure, $\mathrm{E}_{\mathrm{m}}$ - energy (material manufacturing), $\mathrm{C}$ - components; $\mathrm{R}$ - requirements, $\mathrm{S}$ - structure, $E_{L C}$ - energy (life cycle), $S_{a}$ - serviceability [4] 


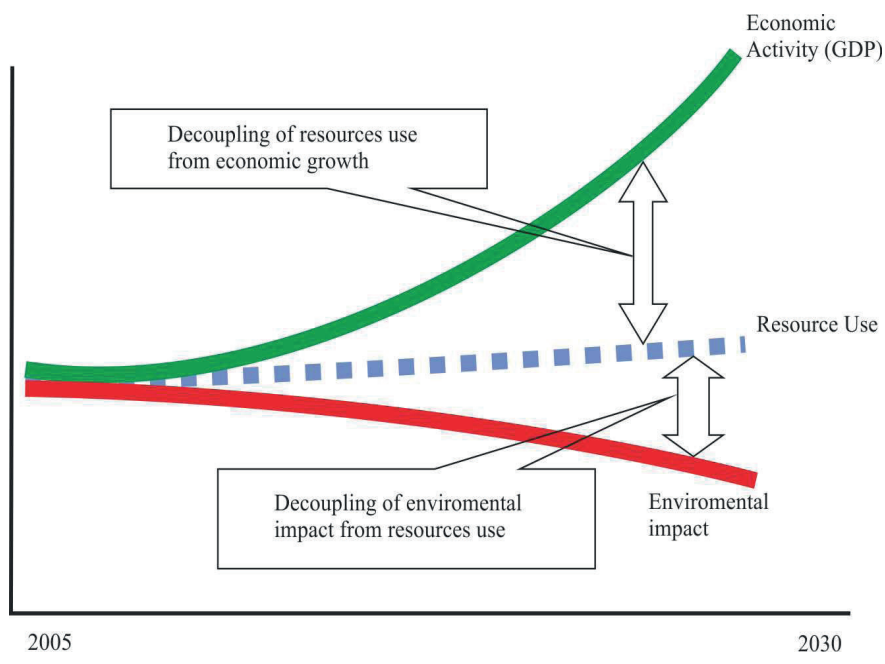

Fig. 2. Ideological presentation of sustainable development: ensuring the growth of GDP (share of construction > 10\%); only a slight

increase in the consumption of resources; reducing the impact on
environment. Modelled according to Illomaki $[6]$

The solution should be contained in the E3-space (energy $\times$ ecology $\times$ economy), i.e. within the limits of minimum energy consumption during the entire "cradle to grave" economic rationale, ensuring the functionality and the comfor of use as well as meeting the basic requirements (see Fig. 4). In other words, the solution should comply with the requirements of sustainable development (Fig. 2) [4]. Two key assumptions are important here:

- the supremacy of the demand for performance (Fig. 3),

- the minimization of criterial features.

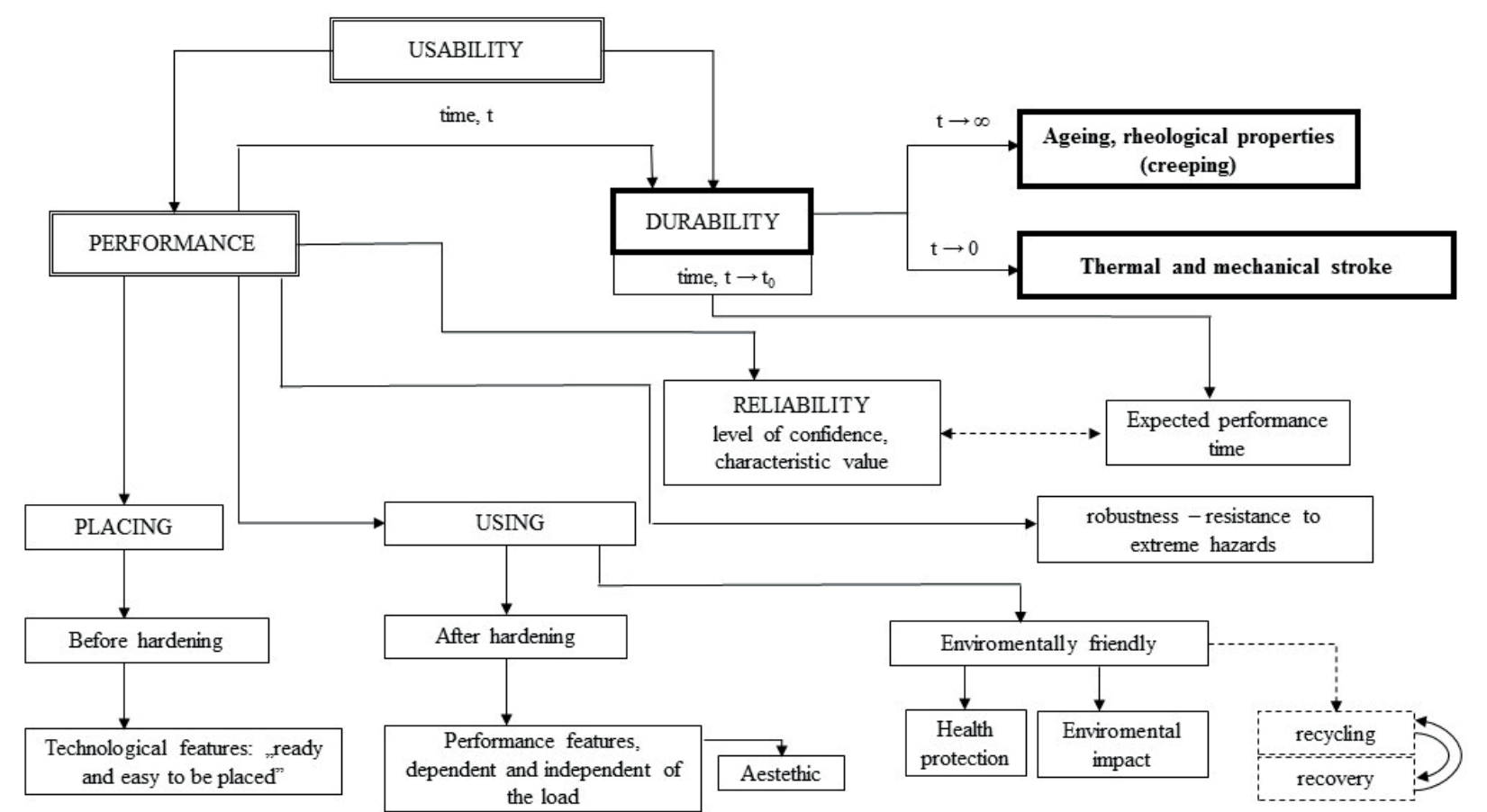

Fig. 3. An example algorithm for formulation of the assessment criteria of the construction product usability $\left(\mathrm{t}_{0}-\right.$ expected performance period) [9] product characteristics (functionality and aesthetics), rather than its specific components and/or materials. We shall be guided here by the 90-year-old idea taken from the US Building Code, 1925 [5]: "Wherever possible, the requirements should be formulated in terms of performance, based on the research results referenced to the performance conditions, and not in terms of the material referenced to the components and the method of preparation. Otherwise, any new material or new material sysems (new sets of already known materials) that could meet the echnical requirements and are satisfactory in economic terms. will encounter barriers that would slow down the technological progress".

This principle is being adopted in the European construction industry very slowly. It was not until 10 years ago in the Conconcrete in PN-EN 206 that it became acceptable to define (a) composition.

Minimisation of criterial features means that we need to draw conclusions from the fact that it is the user who will pay for the unused technical characteristics, both related to the quality (unnecessary features) and the value (excessive range) Rational performance criteria are the choice of both the features (size) and the numbers / criterial ranges (value). At the same time, not all of the required characteristics will need to be verified. Aggregated features may appear, and the decision regarding a further research programme is taken only once it has (eetermined whether these features have been met or not. Assessment methods are subordinated to the performance criterion. We should pay special attention here to the aspect of

The material solution should be formulated in terms of

\begin{tabular}{|c|c|c|c|c|c|c|c|c|c|c|}
\hline 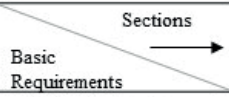 & $\begin{array}{l}\text { Geetechnics } \\
\text { Foundation } \\
\text { Wotrs }\end{array}$ & $\begin{array}{c}\text { Structural and } \\
\text { Material } \\
\text { Mechanics }\end{array}$ & $\begin{array}{l}\begin{array}{c}\text { Consturtion } \\
\text { Materials } \\
\text { Engnine-ing }\end{array} \\
\end{array}$ & $\begin{array}{l}\begin{array}{c}\text { Consturion } \\
\text { hhysics }\end{array} \\
\end{array}$ & 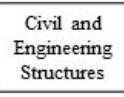 & $\begin{array}{c}\text { Santiar } \\
\text { Enginine }\end{array}$ & $\begin{array}{l}\begin{array}{c}\text { Fire Safety } \\
\text { Engineering }\end{array} \\
\end{array}$ & $\begin{array}{l}\text { Enviriomental } \\
\text { Impect } \\
\text { Engineering }\end{array}$ & $\begin{array}{l}\text { Consturtion } \\
\text { Undettanins } \\
\text { Engninering }\end{array}$ & $\begin{array}{c}\text { Communications } \\
\text { Engnineering }\end{array}$ \\
\hline $\begin{array}{c}\text { Mechancica Resitsance } \\
\text { and thaboity }\end{array}$ & $\star$ & $\star$ & $\star$ & & $\star$ & & $\star$ & & & \\
\hline $\begin{array}{l}\text { Hygiene and Health, } \\
\text { Enviroment }\end{array}$ & $\star$ & & $\star$ & $\star$ & $\star$ & $\star$ & $\star$ & 市 & $\star$ & \\
\hline Safety of use & & $\star$ & $\star$ & $\star$ & $\hbar$ & $\star$ & $\star$ & $\star$ & $\star$ & $\star$ \\
\hline Fire Safety & & $\star$ & $\star$ & $\star$ & $\star$ & & خ & & & \\
\hline Protection against noise & $\star$ & $\star$ & $\star$ & $\star$ & $\star$ & $\star$ & & $\star$ & & \\
\hline Energy Saving & & $\star$ & $\star$ & $\star$ & $\star$ & $\star$ & & $\star$ & $\star$ & $\star$ \\
\hline $\begin{array}{l}\text { Sustainable use of } \\
\text { reseurces }\end{array}$ & $\star$ & $\star$ & $\star$ & $\star$ & $\star$ & $\star$ & & $\star$ & $\star$ & $\star$ \\
\hline Durability & $\star$ & $\star$ & $\star$ & $\star$ & $\star$ & $\star$ & $\star$ & $\star$ & $\star$ & $\star$ \\
\hline
\end{tabular}

Fig. 4. Archetype of the science of construction

result [7], and, therefore, the number of repetitions or sampling [8] and, consequently, the cost of the assessment. In general, heterogeneous products are used in construction. It is importan to strive to obtain accurate values, i.e. average values converging to real and precise values, which means repeatable and reproducible results. The task of an appraiser is to read these criteria and conduct an assessment in a manner suited to a given building.

\section{Matrix of the science of construction}

Construction is of a multi-faceted nature. How the ten sections of construction, listed horizontally in Fig. 4, deal with seven basic requirements listed vertically in Fig. 4, may be assumed to be the archetype of the science of construction (Fig. 4). Due to the functions and safety guarantees which buildings have to fulfil, the Basic Works Requirements [10] have always been formally and legally imposed to the construction industry since the times of Hammurabi [9].

Specifically in construction the design and execution engineers face a fascinating challenge with relation to time - durability, and in relation to space and size from nano- to kilometres. There is no other engineering field where the life cycle of the engineering work can be measured in multiples of the creator's life. The durability requirement is usually over 50 years, and often buildings are expected to have even longer life cycles (monumental buildings). This means that it is not enough for building to meet the requirements at the time of testing. We need to ensure that it will also meet those requirements in the future: for how long are the performances assured? The building service life must be predicted: a prognosis of service life is needed $[11,12]$. This is an extremely complicated issue. At the engineering level, for instance, more than 30 factors can be mentioned which affect the durability of concrete structures (Fig. 5).

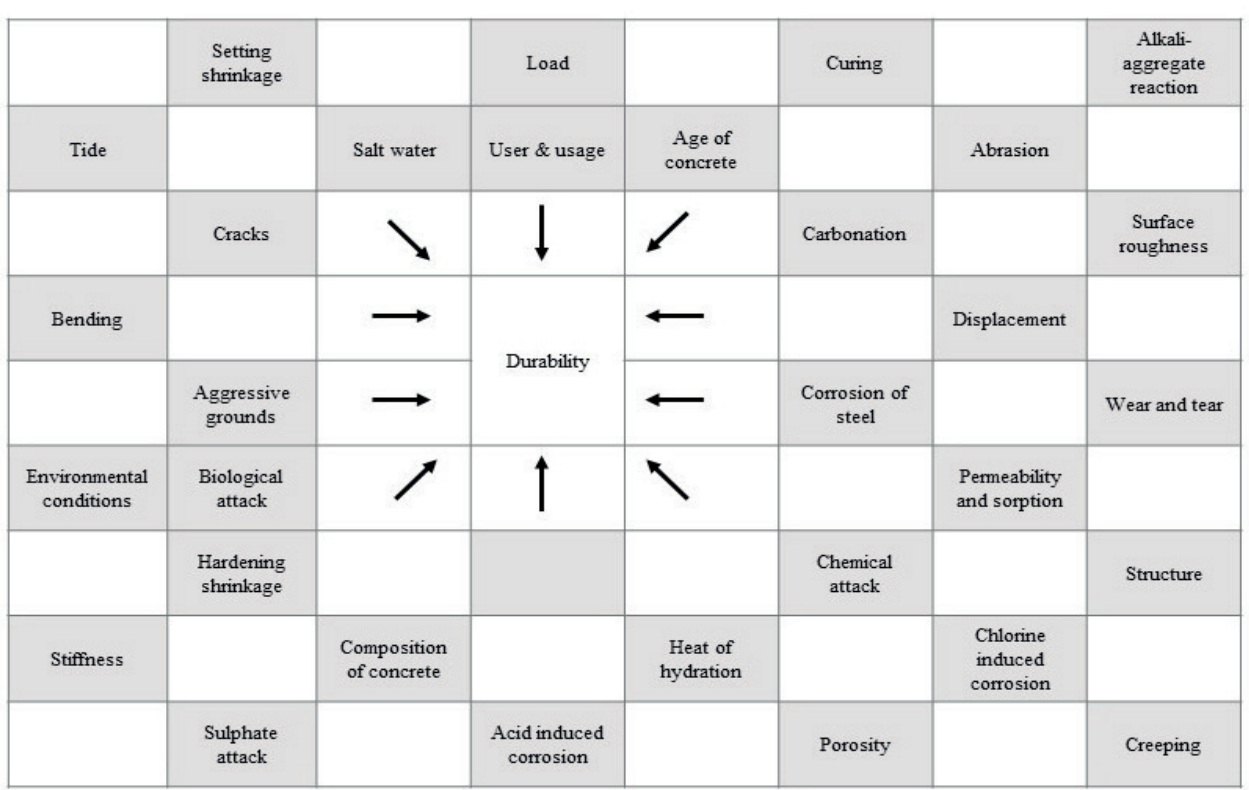

Fig. 5. Factors which affect the durability of concrete structures - engineering level (according to Engineered Material Solutions, EMS 
A huge development of diagnostic methods is occurring. In 2015, a special issue of the Bulletin of the Polish Academy of Sciences. Technical Sciences dedicated to diagnosis and durainse: K. Flag [14]: Z Owsiek [13]. S $[15,16] ;$ Z. Rusin th issue: K. Maga [14]; Z. Owsiak et al. [15, 16]; Z. Rusin et al. al. [19]; K. Wilde et 11. [20]; A. Garbacz [21]; Z Hoła [22]; M. Iwański [23]; A. Szydło [24]; A. Piekarczuk et al. [25]; M. Kolbrecki [26]; D. Kowalski et al. [27] are considerable M. Kolbre [23]; A. Szydo [24; A. Pi In civil engineering we are facing a wide scope of reseach topics, on objects with sizes spanning 15 orders of magnitude At the nano level $\left(10^{-9}-10^{-7} \mathrm{~m}\right)$ we form the propertics of a material, at the micro level $\left(10^{-7}-10^{-5}\right)$ - we form the microstructure and recognise flaws that define performance and durability and at the engineering level $\left(\right.$ macro: $>10^{-1} \mathrm{~m}$ ) we produce building components and erect and use the building. Size versus complexity determines how complicated the research issues are which we face in civil engineering area (Fig. 6). In the engineering of construction materials, there is also a tendency to control the properties at an ever lower - more subtle level of the microstructure:

- $\mu \mathrm{m}$ - in ordinary concrete technology,

- $\mathrm{nm}$ - in high-performance concrete technology, including polymer-cement concrete,

- at the atomic level in ceramics.

When considering the construction - environment relationship [29], it is worth mentioning that:

- $70 \%$ of utilised matter (in particular energy) is absorbed not during erection, but while the building is used. Hence the demand for an overall assessment of a "cradle to demolition" type, and the demand for reuse, recycling, use of recycled and waste materials, as well as environmentally friendly operation. Once again this emphasises how important it is to define performance in accordance wit technical characteristics, not with the composition;

- construction consumes more than $40 \%$ of the produced energy;

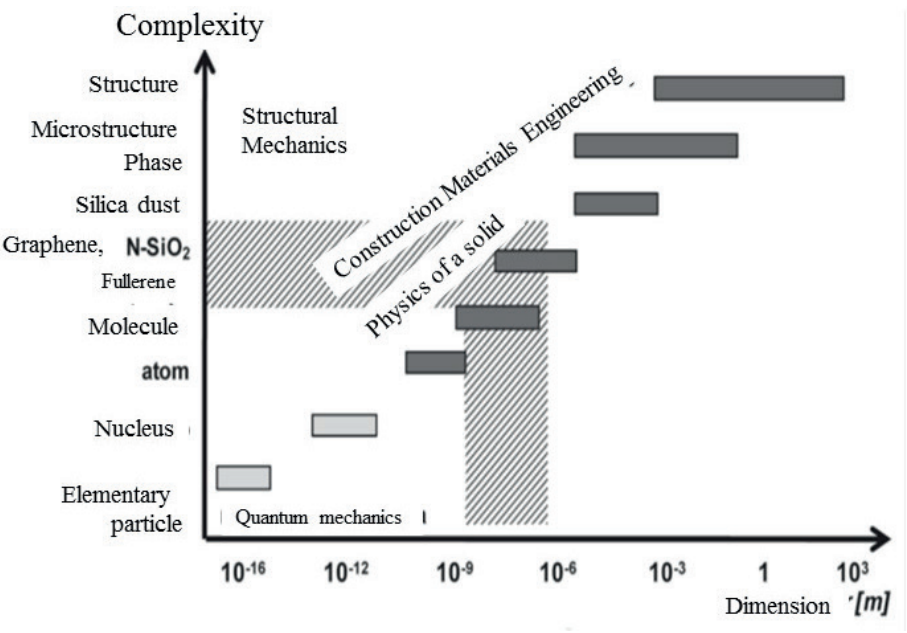
Fig. 6. Schematic representation of the complexity of the resear
issues at the level of "size-complexity"(according to [28])
- approx. $50 \%$ of weight of the materials being processed; - over $30 \%$ of total water consum

- produces $30 \%$ of waste.

Assigning construction to the rules [6] of sustainable develpment is therefore a necessity of civilisation. Whereas in the EU only from $1^{\text {st }}$ of July 2013 the sustainability requirements became obligatory, very soon after in 2015, this argument was reinfored with transcendental considerations. The Holy See (Sancta Sedes in Vatican City) issued the "Laudato Si': On Care For Our Common Home" encyclical (18 June 2015). The encyclical points out the need for a new dialogue about the future of our planet and the recommendation to avoid ecological misconduct.

\section{Rules of thumb}

Science and engineering intermingle within the scientific discipline of construction and sometimes it is difficult to determine the demarcation line. Radomski [30] points out that "discovor an the new is a scientific action, and seeking improvement known is a technical action". Furthermore, as shown by the quoted matrix (Fig. 4), there is a great diversity of problems in the construction area. All these considerations mean that the construction industry uses a relatively large number of "rules of thumb" [31-35], perhaps even more than any other sector of technology [36]. These rules, known as the "rules of thumb", have been formed due to many years of observation and experience, thanks to which correlations were found between different properties of a given substance or between different substances, as well as between various factors within a given process.

In the past, a classic illustration was the paradigm to design effective roof waterproofing protection: a three layer felt flat roof using cold adhesive. The classic rules of thumb include an indication that the minimum dimension of the concrete element should be three times as big as the maximum aggregate grain to avoid concrete pouring problems as well as to obtain a quasi-homogeneous material. The classic scientific rules may include the Bolomey equation, whereby it is possible to determine the compressive strength of concrete based on the water cement $(w / c)$ ratio. Concrete technologists, knowing the concrete compressive strength, may "intuitively" estimate most of the other technical characteristics of this concrete (in a group of types of ordinary concrete). A technologist also knows that if a hand immersed in the sand comes out dirty, the clay content is beyond the acceptable level. They also know that adding 4 litres of water per $\mathrm{m}^{3}$ to an ordinary concrete mix would increase the slump (consistency) by approx. $25 \mathrm{~mm}$, would reduce the compressive strength by approx. $2 \mathrm{MPa}$, and would increase the shrinkage by approx. $10 \%$. Similarly, increasing the air content by $1 \%$ would cause a decrease in the compressive strength by approx. 1.5 MPa. It should be noted, though, that concrete additives are unable to change a poor concrete mix into good concrete, they are only able to make better concrete out of a good concrete mix.

The Arrhenius rule, which has obtained scientific status, states that a 10 degree increase in temperature doubles the rate of a chemical reaction, i.e. the reinforcement corrosion rate is twice as high. Recently, the Arrhenius equation has been recommended [37, 38] in modelling of concrete maturity, which enables the calculation of concrete strength development in the given combination of temperature and time [39].

The Boyer-Beaman rule is not as widely known, although it says that the ratio of glass transition temperature to the melting point in a polymer is a constant value, $\mathrm{Tg} / \mathrm{Tm}=$ const. Within the heat treatment of concrete we may consider a series of rules (Saul, Ganin) which reduce the setting time. In relation to massive structures it is known that each $10 \mathrm{~kg} / \mathrm{m}^{3}$ increase in the content of cement in the mix would cause an increase in the temperature of the "fourth day" by 13 degrees, which is important for cold weather concreting.

Design of spillways in hydraulic structures largely relies on experimentally derived formulas. As an example, Flamant's simplifying formula [40] gives the discharge of water throug a rectangular spillway as a function of the water head H, Fig-7.

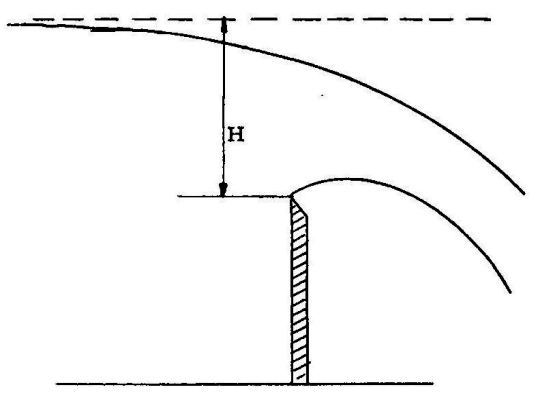

[m³/s.m width of spillway]

Flamant

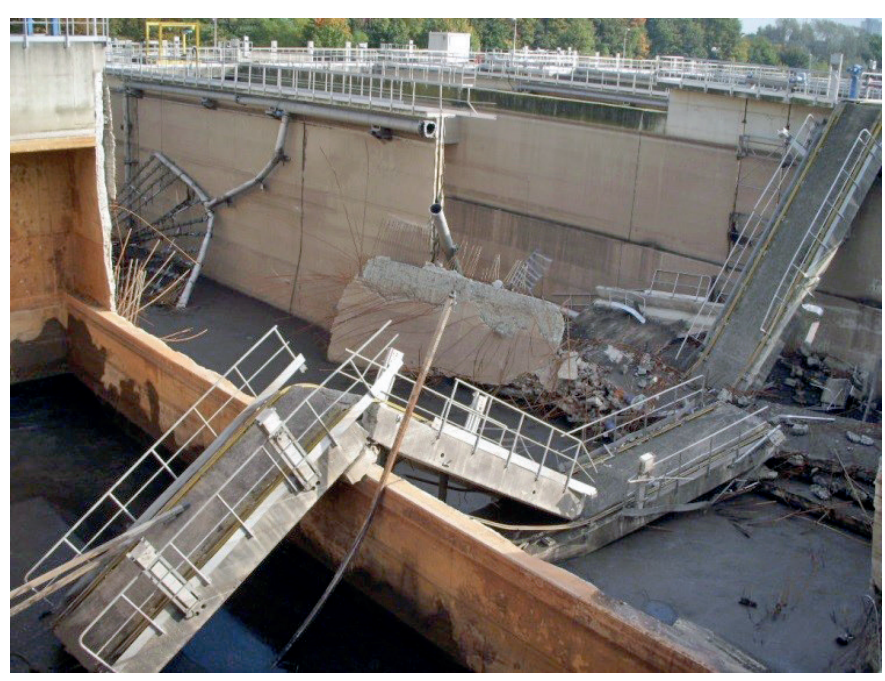

Fig. 8. Collapse of separation wall between full basin at down lef, and emptied basin at right
This formula might have been used to calculate the water levels in the basins of a large (about 200,000 population equivalent) water purification station in Antwerp as a function of expected discharges during rain periods. In September 2012, after some rainy days, a separation wall between two adjacent basins collapsed during the night, Fig. 8.

Estimations of the discharge varied between 6000 (design discharge in 2002) and about $15000 \mathrm{~m}^{3} / \mathrm{hour}$ (duing exploitation afterwards), corresponding to an increase of water head of $0.6 \mathrm{~m}$. During the decade before collapse, this caused no direct problem. However, at the time of collapse the adjacent basin was empty, because maintenance works at the aeration installation were planned, and because of that full water loading was acting on the separation wall, which together with some material defects led to the collapse of the upper half of the tenmeter-high wall. Due to the water pressure, that upper part was smashed against the opposite wall of the empty basin, Fig. 8 , which also collapsed. Of course, the footbridge supported by the walls also collapsed. Fortunately, the collapse took place during the night, when no technicians were at work at the bottom of the adjacent basin. If someone had checked the situation with Flamant's simple formula, which is given in all university civil engineering textbooks on basic hydraulics of open channels, at least the imminent danger would have been recognized, and necessary precautions could have been taken

We should remember, though, that the rules of thumb represent only an approximation of reality, often an inadequate one, and therefore, they may be subject to considerable uncertainty. They are often formulated as statistical correlations. This imposes the need to stay particularly cautious in order to avoid the illusory associations, i.e. to demonstrate statistical significance despite the absence of the cause and effect relationship. However, even the apparently "illusory associations" are in some case useful in an engineering meaning. Lots of equations exist in concrete technology, describing various physical features in relation to a compressive strength $\left(f_{c}\right)$. In physical meaning such relations do not exist. There is usually an indirect relation via porosity content. But in practical meaning they are very useful anyway.

\section{Threats and precautions: precision}

and accuracy, validation and verification

The lexical meaning of rule of thumb is:

- a method or procedure based on experience and common sense

- a general principle regarded as roughly correct but not intended to be scientifically accurate.

Due to the responsibility involved with the engineering works the meaning of rules of thumb in civil engineering is restricted to the first statement. In such situation the rules of thumb in civil engineering are beyond the name, much more close to a heuristic technique. It means an approach to problem solving that employs a practical method which is probably approximately correct, and which is sufficient for the immediate goals. 
Civil engineering activity needs and requires that rules of thumb should be in certain range (frequently $\pm 3 \times$ standar deviation - and this represents a rule of thumb as well) of preto estimate uncertainty.
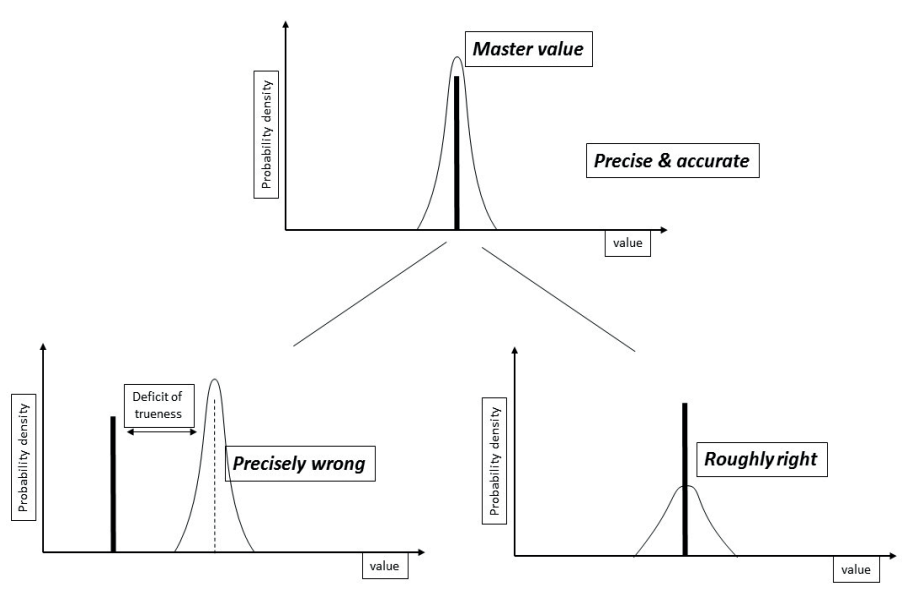

Fig. 9. Accuracy and precision of the statement

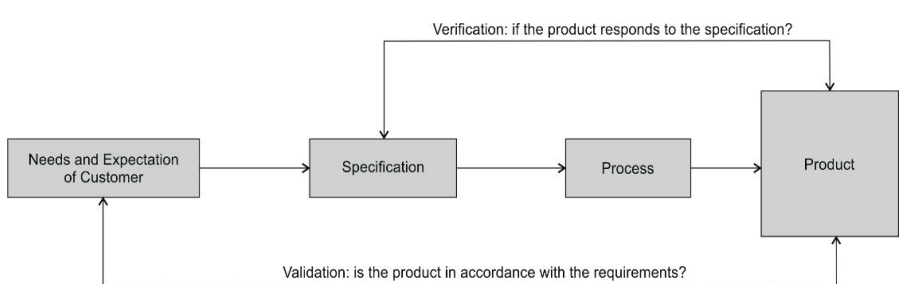

Fig. 10. Verification and validatio

Verification and validation are two terms which originally came from information technology, but in present time are spread out on other domains as well. A verification takes place before validation. Verification evaluates documents, plans, codes, requirements and specifications. Experimental validation is the final check to reveal possible errors and to estimate the accuracy of the simulation. Validation can be practically split into three tasks:

- to detect and separate the model's significant discrepancies,

- to remove and reduce removable and unavoidable errors, - to evaluate uncertainties in the result.

Shortly, verification replies to the question: was the right product applied or built in the right way? and validatio answers on: does the built product meet the required performances?

The uncertainty resulting from tests is a combination of parameter (material properties and element geometry) and model uncertainty and may be considered in terms of both, the probability(parameter uncertainty) and the approximate reasoning (model uncertainty). In this paper the authors focus mainly but not solely on the analytical modelling.
Probabilistic analysis methods can be used to predict the OLSKA AKADEMIA NAb because the bell tower of the Saint Eustachius church in Zichem ime to failure of existing constructions, taking into account load material and geometrical uncertainties. Viscolo account elling will do beh the ate leading to failure) [44]

Alarmed by the collapse of the bell tower of the church in Meldert on July 6, 2006 (Fig 11) the stability of the tow of the Saint Eustachius as this tower was bilt with the sacte sadsone showed a similar damage pattern at its base.

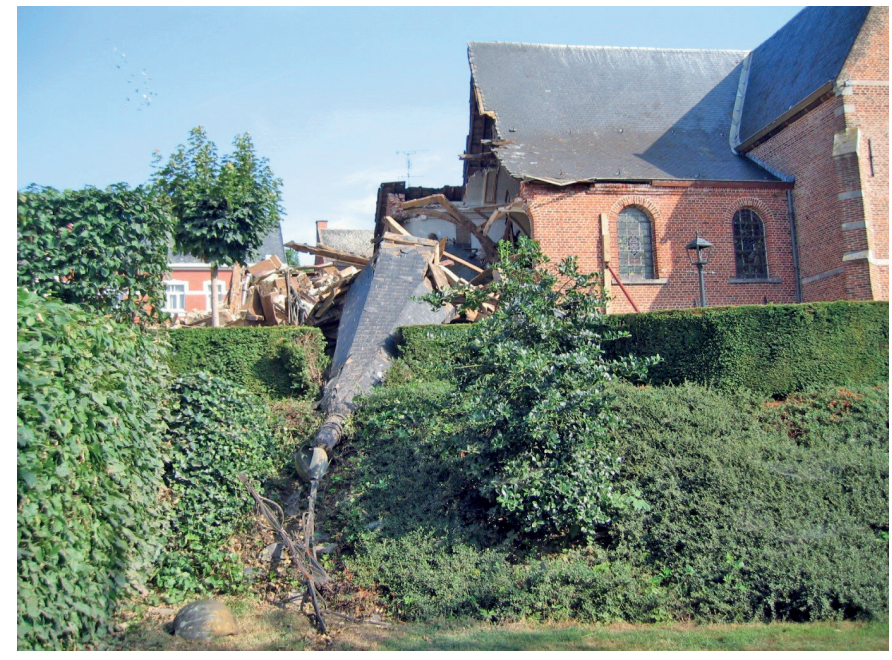

Fig. 11. Collapse of bell tower of St Willibrordus church at Meldert

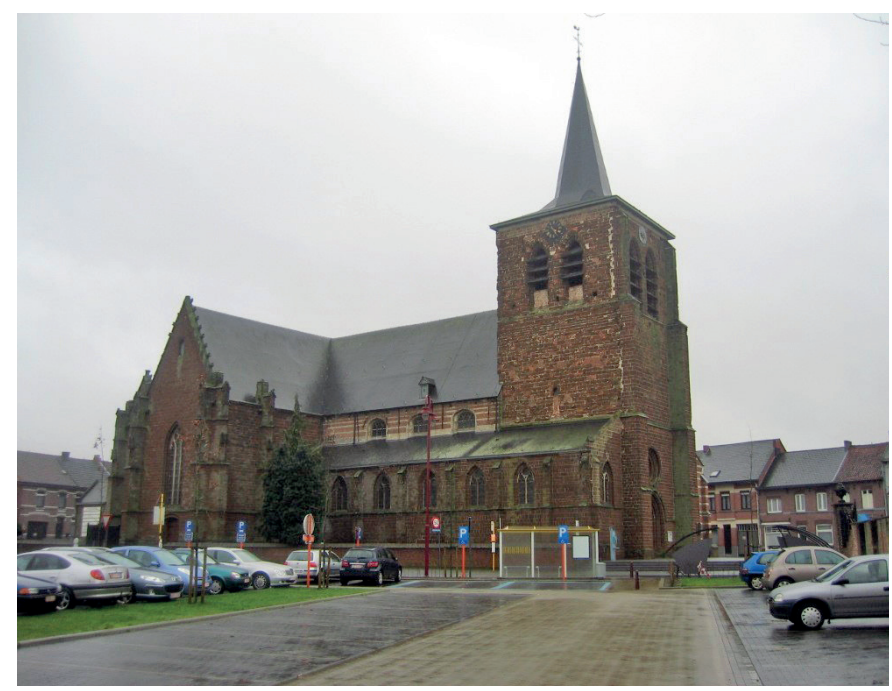

Fig. 12. St Eustachius church in Zichem

With a probabilistic analysis, based on Monte Carlo sampling, the failure probability of the church in Zichem was estimated for the relative stress level, present in the interio pillars of the tower $(55.4 \%)$ and for a time frame of 700 years, was constructed in the early 14th century. From this analysis, determinicic callo this bell tower, the pobbilic anlys estinat a

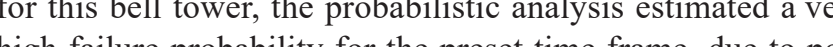
masonry.

Because the calculations did not guarantee the tower's structural safety, and having in mind the collapse in the year before of the tower in the nearby village, the risk was considered too high and strengthening measures were proposed and swiftly executed in 2007 [45]. The bases of the columns of the tower were strengthened by constraining the lateral deformation with epoxy bonded Carbon Fibre Reinforced Polymer sheets (CFRP), as shown in Fig. 14

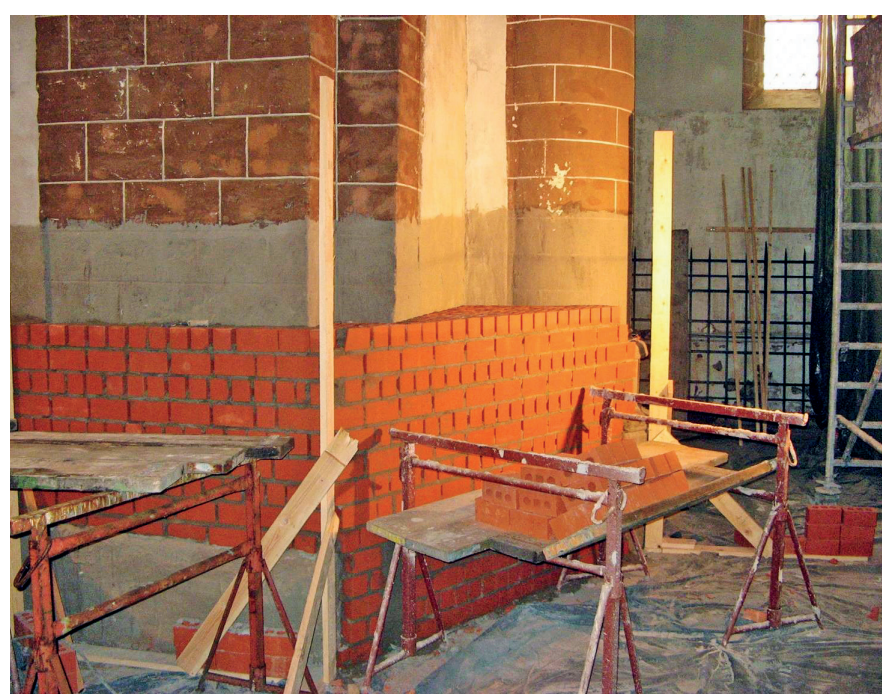
section

The constraining effect of the CFRP sheets increases the load bearing capacity of the pillars. The wrapping of the pillars was designed as a temporary measure, to ensure stability until an take place. This would include grout injections to increase the internal coherence of the pillars as well as the overall strength of the masonry.

In this case the general opinion of the public says that a building which was stable during the past 500 years, will also remain stable during the next 500 years. In this case this rule of thumb has been overruled.

The authors wish to believe that this was due to their probabilistic analysis. However, they are aware that the nearby collapse of a similar tower might have had a much greater impact on the decisions.

In the era of computer-aided design, $\mathrm{CAD}$, and building information modelling, BIM, sometimes the rules of thumb are cited with some embarrassment. But there are many reasons to extensive strengthening and consolidation campaign could

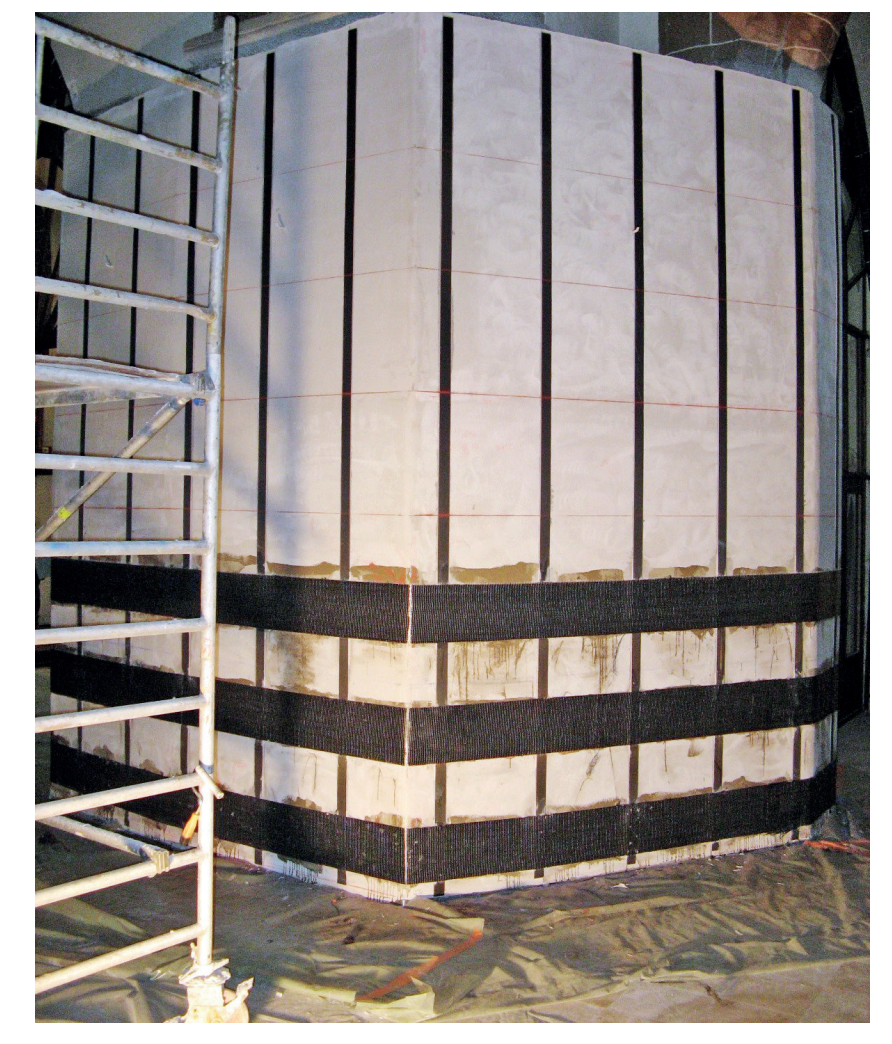

Fig. 14. CFRP-constraining strips around column base during execution

believe that the significance of the rules of thumb should not

- widespread use of computer programmes often creates students and young engineers in the virtual world far away from the building site and construction. Then, the probably approximately correct value may perform the functions of a common-sense verification. Certainly, one cannot say that construction technology has already been developed to the limits of comprehension [41]. But for sure the rules of thumb are milestones in reality. Already at the very beginning of the virtual world in 1966, R. L'Hermite [42] stated about researchers and research publications: "Tout d'abord, aucune publication ne doit sortir d'un institut sans avoir été soumise à son directeur scientifique. ... Au lieu de se hâter de publier, qu'ils prennent le temps de mûrir leur affaire. ... Le défaut de la publication hâtive est celui des jeunes; lorsqu' on avance en âge et malgré que le temps presse apparemment il est courant de re macerer quel lon publie moins souven et de meilleure façon". Reflections which are valid for researchers hold even more for civil engineering design engineers.

- rules of thumb help to preserve and even revive the engineering intuition and prevent "re-inventing of the wheel",

- rules of thumb help to keep the link between science and engineering, while the immersion of science and technology within civil engineering is becoming more and more obvious. 
However, we should add three more rules of thumb for general use:

in order to find accurate information on the Internet at least nine irrelevant pieces of information must be rejected (a rule of 90:10 according to Banerjee);

- a rule of 80:20 according to Koch says that $20 \%$ of ou efforts bring $80 \%$ of benefits, but it is believed that in structural design Hyde's rule of 5:90 is applicable [43] - the last $5 \%$ of the design takes $90 \%$ of the total time. But even the missing $5 \%$ or $20 \%$ of the design efforts are responsible of the vast majority of structural defects, and they provide the nutrient ground for a flourishing repair industry in construction.

And to conclude:

- the golden rule according to George Bernard Shaw says tha there are no rules. However, he was not an engineer.

\section{Summary}

The statement in the introduction that "it is better to be roughly right than precisely wrong" (J.M. Keyness) makes us realise the dilemma of accuracy and simplification, of how our data and models are far from the truth and what consequences this might have for the field of safety and reliability. Estimating this "distance from truth" and its effects gradually progresses, based "distance from truth" and its effects gradually progresses, based
on scientific grounds. However, the significance of the rules of
thumb and engineering intuition based on technical knowledge has also been presented. It is estimated that there are nearly 300 million websites of unstructured scientific reports available on the Internet; each year 5,000 publications on the subject of concrete alone are issued. On the other hand, in technology, and especially in construction, the improvement of professiona skills only by practice is not sufficient and may even be dangerous. The very nice English phrase learning by doing may come down to error method.

\section{REFERENCES}

[1] L. Czarnecki, "Kształtowanie naukowych podstaw rozwoju budownictwa", Materiaty Budowlane 11, 7-10 (2015), [in Polish].

[2] L. Czarnecki and J.J. Sokołowska, "Material model and revealing the truth", Bull. Pol. Ac.: Tech. 63 (1), 7-14 (2015).

[3] L. Czarnecki, I. Hager, and T. Tracz, "Material problems in civi engineering: Ideas-driving forces-research arena", Procedi Engineering 108, 3-12 (2015)

L. Czarnecki and M. Kaproń, "Sustainable construction as vials Engineering for Resources 17, 99-106 Society of Mate-

"Recommended practice for arrangement of buildin Report of building committee", Washington Governmes Printing Office, 1925, http://hdl.handle.net/2027/uc1.\$b78828.

[6] A. Illomaki, "European horizontal standards for sustainability of building - one system in Europe", ftp.cen.eu/cen.
[7] E. Szewczak, "Ryzyko związane z niepewnością wyników badậ́ 1 ocena zgodnosci wyrobow budo
lane 10, $73-75$ (2011), [in Polish].

[8] E. Szewczak and A. Bondarzewski, "Is the assessment of interlaboratory comparison results for a small number of tests and limited number participants reliable and rational?", doi:10.1007 s00769-016-1195-y, Accreditation and Quality Assurance 21 (2), 91-100 (2016).

[9] L. Czarnecki, "Wyzwania inżynierii materiałów budowlanych", Inżynieria i Budownictwo 64 (7), 404-408 (2008), [in Polish].

10] CPR No. 305/2011 Annex 1, "Construction Products Regula-

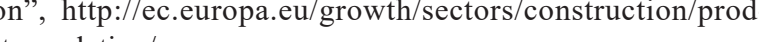

1] L. Schueremans and D. Van Gemert, "Effectiveness of hydrophobic treatment as chloride penetration barrier - on the site
investigations and service life prediction model", 5th International Colloquium Materials Science and Restoration "MSR'99", Technische Akademie Esslingen MSR V, Aedificatio Publishers, $731-740$ (1999).

12] E. Verstrynge, L. Schueremans, D. Van Gemert, and M. Wevers, "Monitoring and predicting masonry's creep failure with the 42, 518-523 (2009).

[13] L. Czarnecki and W. Trąmpczýnski, "Diagnostics and durability Dof civil structures", Bull. Pol. Ac. Tech. 63 (1), 3-5 (2015)

114] K. Flaga, "The influence of concrete shrinking on durability

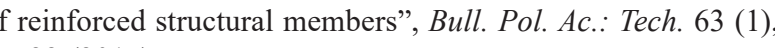

15-22 (2015).
15] Z. Owsiak, J. Zapała-Staweta, and P. Czapik, "Diagnosis of concrete structures distress due to alkali-aggregate reaction", Bull. Z Ow. Tech. 63 (1), 23-30 (2015).

Pol Ac. Tech 63 (1) 31-34 (2015).

Z. Rusin and P. Swiercz, "Volumetric strains of cement-based mortars caused by ice formation in terms of frost resistance diagnostics", Bull. Pol. Ac.: Tech. 63 (1), 35-42 (2015).

18] L. Czarnecki and P. Woyciechowski, "Modelling of concrete carbonation; is it a process unlimited in timeand restricted in space?", Bull. Pol. Ac.: Tech. 63 (1), 43-54 (2015).

19] B. Goszczyńska, G. Świt, and W. Trąmpczyński, "Analysis of the respect to the service life of reiforced concrete stretures with the example of RC beams", Bull. Pol Ac. Tech 63 (1), 55-64 (2015).

20] M. Rucka and K. Wilde, "Ultrasound monitoring for evaluation of damage in reinforced concrete", Bull. Pol. Ac.: Tech. 63 (1), 65-76 (2015)

21] A. Garbacz, "Application of stress based NDT methods for concrete repair bond quality control", Bull. Pol. Ac.: Tech. 63 (1),

22] J. Hoła, J. Bień, Ł. Sadowski, and K. Schabowicz, "Non-dein assessment of their durability", Bull. Pol. Ac. Tech. 63 (1), $87-96$ (2015).

23] M. Iwanski and A. Chomicz-Kowalska, "Evaluation of the pavement performance", Bull. Pol. Ac.: Tech. 63 (1), 97-106 (2015).

24] J. Kuźniewski, Ł. Skotnicki, and A. Szydło, "Fatigue durability of asphalt-cement mixtures", Bull. Pol. Ac.: Tech. 63 (1), 107 $112(2015)$
A. Piekarczuk, K. Malowany, P. Więch, M. Kujawińska, and P.
Sulik, "Stability and bearing capacity of arch-shaped corrugated A. Pill, "S Ac.: Tech. 63 (1), 113-124 (2015)

[26] A. Kolbrecki, "Model of fire spread out on outer building surface", Bull. Pol. Ac.: Tech. 63 (1), 135-144 (2015).

[27] D. Kowalski, B. Kowalska, and M. Kwietniewski, "Monitoring of water distribution system effectiveness using fractal geometry", Bull. Pol. Ac.: Tech. 63 (1), 155-161 (2015).

[28] M.W. Grabski and J.A. Kozubowski, Inzynieria materiatowa.

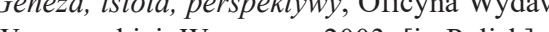

L. Czarnecki, M. Kaprón, M. Piasecki, and

, i Budownictwo 68 (1), 18-21 (2012), [in Polish].

[30] W. Radomski, "Nauka w inzynierii ladowej a rola instytutu techniki budowlanej", in Strategia instytutów badawczych budownictwa, pp. 17-38, ed. L. Czarnecki, Instytut Techniki Budowlanej, 2015, [in Polish].

[31] H. Heywood, 101 Rules of Thumb for Sustainable Buildings and R. Smiles, RiBA Publishing, 2015.

[32] R. Smith and R.K. Mobley, Kules of Thumb for Maintenance and

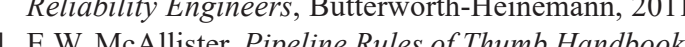

De Pipeline Engineering Problems, Gulf Professional Publishing, 2015.

[34] R.A. Rajapakse, Geotechnical Engineering Calculations and

Rules of Thumb, Butterworth-Heinemann, 2015.

R.A. Rajapakse, Plle Design and Construction Rules of Thumb. Butterworth-Heinemann, 20
D. Fisher, Rules of Thumb for Engineers and Scientists, Gulf Publishing Company, 199

to aprinio and H.S. Lew, "The maturity method: From theory Exposition, ed. P.C. Chang, American Society of Civil Engineers, Washington D.C., 1-19 (2001).

[38] W. Kurdowski and P. Pichniarczyk, "Problems with the ArrheWhe Lime Concrete 3, 149-156 (2016), [in Polish and English].

39] J. Bobrowicz, "Influence of reduced temperature and admixtures on hydration of cements", Cement Lime Concrete 3, 177-190
(2016), [in Polish and English].

40] A.-A. Flamant, Hydraulique, Li

ie Polytechnique C. Béranger,

41] S. Arbesman, Overcomplicated: Technology at the Limits of Comprehension, Penguin Random House LLC, 2016.

R. LHermite, De la recherche appliquée à la recherche pure, sels, 1966 [in French].

43] J. Hyde, "Getting chartered: the last 5\%, being brunel", www.beingbrunel.com/getting-chartered-the-last-5.

44] E. Verstrynge, L. Schueremans, and D. Van Gemert, "Creep and and repair options", Construction and Building Materials 29 , doi: 10.1016:j. conbuildmat.2011.10.042, 149-157 (2012).

45] E. Verstrynge, L. Schueremans, and D. Van Gemert, "Los behaviour of monumental masonry constructions: assessment methodology and case studies", Bausubstanz, Zeitschrift für nachhaltiges Bauen, Bauwerkserhaltung und Denkmalpflege 2, $48-53(2012)$ 